\title{
Data-driven weights and restrictions in the construction of composite indicators
}

\author{
Ana Perišicín ${ }^{1, *}$ \\ ${ }^{1}$ Polytechnic of Šibenik \\ $\operatorname{Trg}$ A.Hebranga 11, 22000 Šibenik, Croatia \\ E-mail: 〈sisak@vus.hr〉
}

\begin{abstract}
Composite indicators are increasingly recognized as a useful tool in policy analysis and public communication. However, if poorly constructed, they can send misleading policy messages. Perhaps the most difficult aspect of constructing a composite indicator is choosing weights for the components. The categorization of Croatian territorial units for development policy is based on the value of the composite indicator called the development index. The main goal of this paper is to propose an empirical approach for weight selection. In order to generate the set of non-subjective weights, principal component analysis and linear programming methods have been applied. An application of data envelopment analysis to the field of composite indicators, known as the Benefit-of-the-Doubt approach, has been demonstrated subject to proportional subindicator share restrictions. Additionally, the Monte Carlo simulation of weights was conducted, and confidence intervals for the values of the development index were estimated. Owing to the fact that the examined weighting schemes have resulted in the different categorization of territorial units, use of unit-specific weights and incorporating uncertainty in the construction of a composite indicator looks promising for further work.
\end{abstract}

Key words: composite indicator, development index, weighting, principal component analysis, benefit of the doubt

Received: September 29, 2014; accepted: December 12, 2014; available online: March 30, 2015

DOI: 10.17535 /crorr.2015.0003

\section{Introduction}

Composite indicators (CI) are increasingly recognized as a tool for policy making in a wide range of fields such as the environment, economy and human development. The construction of CIs involves stages where subjective judgments need to be made: selection of indicators, treatment of missing values, choice of aggregation model and weights of indicators, etc. These choices can even be used to manipulate results [4]. The inescapable subjectivity involved in

* Corresponding author. 
their construction is often invoked to undermine the credibility of CIs, thus it is important to identify the sources of subjectivity. Therefore, sensitivity and uncertainty analysis should be undertaken to assess the robustness of CIs. The absence of an objective way to determine weights and aggregation methods does not necessarily lead to a rejection of the validity of CIs, as long as the entire process is transparent [12].

Assessing the development level of territorial units is crucial for regional planning and development policy, and is a key criterion for allocating various structural funds and national subsidies [5]. There are several different approaches to assessing regional development level. This paper is focused on CIs, especially on the development index, as a main instrument of Croatian regional policy. This index is a CI, which is calculated as the weighted average of five basic normalized socio-economic indicators: income per capita $\left(X_{1}\right)$, budget revenue per capita $\left(X_{2}\right)$, unemployment rate $\left(X_{3}\right)$, change in population number $\left(X_{4}\right)$, and educational attainment rate $\left(X_{5}\right)$, relative to the national average. The value of the development index for a territorial unit $c$ is calculated using the formula

$$
I_{c}^{G O V}=0.25 x_{1 c}+0.15 x_{2 c}+0.3 x_{3 c}+0.15 x_{4 c}+0.15 x_{5 c}
$$

where $x_{i c}, i=1,2, \ldots, 5$ represent normalized value of a sub-indicator $X_{i}$ for a territorial unit $c$. The indicators and their corresponding weights are determined by a government decree [7]. The index is calculated for a three-year period. In this paper, the development index obtained for the period $2010-2012$ is used.

A priori determination of weights for various components implies the existence of a universally acceptable human development function, which is not the case [14]. This paper proposes a new method for weight selection, which is based on an empirical approach. This approach appears worthwhile pursuing, as it uses non-subjective weights, and thus generates less biased results. The aim of this paper is to contribute to a better understanding of the complexity of CIs, and to improve the techniques currently used to build the development index. In order to generate a set of non-subjective weights, principal component analysis (PCA) and linear programming methods have been applied. Furthermore, an application of data envelopment analysis (DEA) to the field of CIs, known as the Benefit-of-the-Doubt (BOD) approach, has been demonstrated. This approach provides unit-specific weights, ensuring a maximum value of a CI for every territorial unit. Additionally, assuming the weight setting as the only source of uncertainty, a Monte Carlo simulation of weights was conducted and CI values for each territorial unit were calculated. A "random weights" technique was used to test the sensitivity of summary indicator values to different weighting schemes.

The rest of the paper is organized as follows: section 2 describes a methodology used in the construction of CIs and gives a brief overview of the 
government methodology used in the construction of the development index; section 3 is focused on applying data-driven methods to the development index while section 4 gives some concluding remarks.

\section{Composite indicators}

Perhaps the most difficult aspect of constructing a CI is choosing weights for the components. The selection of weights should be done according to the underlying theoretical framework. Existing literature offers quite a rich menu of weighting methods. Some of them, such as factor analysis and PCA, DEA and the unobserved components model, are based on statistical methods and linear programming. On the other hand, participatory methods, such as budget allocation processes, analytic hierarchy processes and conjoint analysis, incorporate various stakeholders - experts, citizens and politicians. Weights that are based on explicit agreements between policymakers as to the desirability of different development goals, derived from policy statements of governments and development agencies, or derived from collective utility functions based on individual preference functions of the particular population, are often singled out for their arbitrariness in weighting [1]. There is no general consensus on using any one of the weighting schemes. The most common is equal weighting, i.e. all variables are given equal weights, due to simplicity and transparency. This essentially implies that all variables are 'worth' the same in the composite, but it could also disguise the absence of a statistical or an empirical basis, e.g. when there is insufficient knowledge of causal relationships or a lack of consensus on the alternative [12]. Weights can be chosen to reflect the quality of data, assigning higher weights to statistically more reliable data. In linear aggregation, it is well known that weights have the meaning of trade-offs, while experts usually interpret weights as importance coefficients. This perception can be grossly off the mark. Nominal weights are not a measure of variable importance and the relative importance of variables depends on the characteristics of their distribution as well as their correlation structure [16]. An overview of different weighting methods (and details viz. scaling, normalization and aggregation) used in the construction sustainability indices can be found in [23].

Multivariate techniques present an empirical and relatively more objective option for weight selection, allowing no control over the selection of a weighting scheme. Apart from weight selection, these techniques can help to investigate some other important issues like the presence of outliers and multicollinearity. Different multivariate methods have been applied to evaluate the development index [17]. PCA was applied in the field of CIs [13] and, especially, to evaluate the development index [18]. PCA enables the reduction of the variables in the multivariate data set by a small number of latent variables. This method may be used to detect outliers to uncover data structures that account for a large 
percentage of the total variance, and to create new hypothetical constructs that may be employed to predict or classify observations into groups [24]. The objective is to explain the variance of the data through a few linear combinations of the original data, minimizing the information loss. The first principal component $I^{1}$ is the linear combination of the standardized variables that has the greatest possible variance.

$$
I^{j}=\sum_{i=1}^{5} w_{i}^{j} X_{i}, j=1, \ldots, k .
$$

Each subsequent principal component $I^{j}$ is a linear combination of the standardized original variables that has the greatest possible variance and is uncorrelated with previously defined components. Various guidelines have been developed on the issue how many linear combinations $k$ should be retained (in the case of development index it is obviously $k \leq 5$ ). The most commonly used technique to determine the number of components to be extracted is the latent root criterion [9]. The main weakness in CIs derived from PCA is the minimization of the contribution of individual indicators which do not move along with other individual indicators (correlations do not necessarily represent the real influence of the sub-indicator!). Furthermore, PCA is sensitive to outlier presence and to modifications in the basic data. PCA derived weights are difficult to interpret and to communicate, and as a result the use of PCA in this context is not widespread [16].

In the absence of specific knowledge about the true weights, it is questionable whether a fixed weighting scheme should be applied, especially since fixed weighting can depreciate some units while favoring others. The DEA approach helps to overcome this issue by allowing unit specific weights. DEA was initially developed by Charnes [2] as a linear programming tool for measuring efficiency of a set of peer entities. The application of data envelopment analysis to the field of the CI is known as "benefit of the doubt approach" (BOD) [12]. This method was originally proposed to evaluate macroeconomic performance. Elaboration of this method as a weighting method can be found in work of Cherchye et al. [3]. A well-known property of the original DEA model [2] is units invariance; i.e. the CI values are independent of the units in which the constituent sub-indicator values are measured [4]. The DEA was already applied in the field of CI providing alternative weighting systems ([11], [8], [3], [4], [22]). It was reported that the use of DEA overcomes some key limitations, the undesirable dependence of final results from the preliminary normalization of sub-indicators, and from subjectivity in weighting [4]. The optimal weights are obtained by solving the optimization problem (3).

$$
\begin{aligned}
& C I^{*}=\max _{w_{i c}} \sum_{i=1}^{Q} x_{i c} w_{i c} \\
& \sum_{i=1}^{Q} x_{i c} w_{i c} \leq 1, c=1, \ldots, C \\
& w_{q c} \geq 0, q=1, \ldots, Q, c=1, \ldots, \mathrm{C}
\end{aligned}
$$


Each territorial unit $c$ has its own optimal set of weights, $w_{i c}, i=1, \ldots, Q$. This guarantees the best position of a unit among all other units in the sample. Though the obtained weights are unit specific, it is possible to estimate a common set of weights using regression [25]. The full flexible optimization problem (1) has two main disadvantages. First, many territorial units achieve the value of 1 , which is the maximum score of a CI, and second, zero weights are assigned to many sub-indicators. Incorporating some available information (expert opinion) about appropriate weights to make the weights acceptable is considered useful. Sub-indicator share restrictions (4) can be interpreted as bounds for the importance of sub-indicators in a composite score [3]. Restrictions on sub-indicator shares provide an easy and natural representation of previous information on the importance of CI components [3]. An introduction to an extended BOD approach subject to restrictions on weights and sub-indicator shares can be found in [3].

$$
\alpha_{q} \leq \frac{x_{q c} w_{q c}}{\sum_{i=1}^{N} x_{i c} w_{i c}} \leq \beta_{q}, \alpha_{q}, \beta_{q} \in[0,1], \mathrm{q}=1, \ldots, \mathrm{Q}, \mathrm{c}=1, \ldots, \mathrm{C}
$$

When using min-max normalization, obtaining sub-indicator share restrictions (4) with $\alpha_{q}>0$ leads to infeasibilities since a normalized indicator value $x_{q c}$ is equal to 0 for at least one territorial unit $c$. In some cases, it is possible to obtain sub-indicator category share restrictions (5) where $\mathrm{S}_{\mathrm{J}}$ captures the category $J$. In the case of the development index, sub-indicators are classified into two categories: demographic and economic category.

$$
\alpha_{J} \leq \frac{\sum_{j \in S_{J}} x_{j c} w_{j c}}{\sum_{i=1}^{N} x_{i c} w_{i c}} \leq \beta_{J}, \quad c=1, \ldots, C
$$

Since the quality of a model also depends on the soundness of its assumptions, good modelling practice requires that the modeler evaluate confidence in the model, assessing the uncertainties associated with the modelling process and the subjective choices taken [12]. Uncertainty analysis focuses on how uncertainty in the input factors (normalization methods, weighting schemes and weight) propagates through the structure of the CI and affects the values of the CI [20]. In this paper, the uncertainty analysis is limited to weight setting as the only source of uncertainty.

\section{Application to the development index}

\subsection{The development index}

The development index provides development level assessment and categorization of units on both regional (20 counties and the City of Zagreb) and local (556 municipalities and towns) level. According to the value of the 
development index, local units are categorized into 5 groups, while regional units are classified into 4 groups [10] as shown in table 1. If a territorial unit has an index value $I_{c}^{G O V}<75 \%$, it is rated as lagging behind in development and thus has a special status and a granted special support from the central level. Table 1 also provides the number of territorial units classified in each group (n).

\begin{tabular}{|c|c|c|c|c|}
\hline & Local level & $(\mathrm{n}=556)$ & Regional level & $(\mathrm{n}=21)$ \\
\hline Group I & $I_{c}^{G O V}<50 \%$ & $(47)$ & $I_{c}^{G O V}<75 \%$ & $(12)$ \\
\hline Group II & $50 \% \leq I_{c}^{G O V}<75 \%$ & $(217)$ & $75 \% \leq I_{c}^{G O V}<100 \%$ & $(3)$ \\
\hline Group III & $75 \% \leq I_{c}^{G O V}<100 \%$ & $(173)$ & $100 \% \leq I_{c}^{G O V}<125 \%$ & (3) \\
\hline Group IV & $100 \% \leq I_{c}^{G O V}<125 \%$ & $(93)$ & $125 \% \leq I_{c}^{G O V}$ & (3) \\
\hline Group V & $125 \% \leq I_{c}^{G O V}$ & (26) & - & \\
\hline
\end{tabular}

Table 1: Categorization of territorial units based on the development index

As mentioned in the first section, the development index is calculated as the weighted average deviation from the national average of five basic indicators (1). Before aggregating into a single value, all of the sub-indicators are normalized. First, a min-max normalization of each sub-indicator was conducted

$$
x_{i}^{N}=\frac{x_{i}-x_{i, \min }}{x_{i, \max }-x_{i, \min }}
$$

Afterwards, the ratio of a normalized sub-indicator was taken respective to the normalized national average

$$
\mathrm{x}_{\mathrm{i}}^{G O V}=\frac{\frac{x_{i}-x_{i, \min }}{x_{i, \max }-x_{i, \min }}}{\frac{x_{i, H R^{-}} x_{i, \min }}{x_{i, \max ^{-}-x_{i, \min }}}}=\frac{x_{i}-x_{i, \min }}{x_{i, H R}-x_{i, \min }}
$$

where $x_{i, \min }=\min _{c} x_{i c} ; x_{i, \max }=\max _{c} x_{i c} ;$ while $x_{i, H R}$ represents a national average of an indicator $X_{i}$. This type of normalization (further called governmental normalization) actually computes the distance to the worst territorial unit respective to the distance of the national average to the worst unit (see formula (7)). Another drawback of the governmental normalization method is its sensitivity to outlier presence. In the collection of Croatian local units, municipality Vir stands out as an outlier [18].

In calculating the development index, the largest weight was assigned to the unemployment rate $\left(w_{3}^{G O V}=30 \%\right)$, sub-indicator incomes per capita weights $w_{1}^{G O V}=25 \%$ while the other three indicators (budget revenue per capita, change in population number, and educational attainment rate) have equal weights $w_{2}^{G O V}=w_{4}^{G O V}=w_{5}^{G O V}=15 \%$. In summary, the economic category $\left(\mathrm{X}_{1}, \mathrm{X}_{2}, \mathrm{X}_{3}\right)$ has a weight of $70 \%$ and the demographic category $\left(\mathrm{X}_{4}, \mathrm{X}_{5}\right)$ a weight of $30 \%$. The weights were assigned based on expert opinion concerning their relevancy for development level assessment [19]. Still, this failed to ensure the relevance of each sub-indicator in computing CI. When analyzing the contribution of a sub-indicator or category to the overall value of CI, i.e. sub-indicator shares or category shares (these are in fact products $x_{i c} w_{i c}, i=1, \ldots, 5, c=$ 
$1, \ldots, C$ or the sum of the products $\left.\sum_{i=1}^{3} x_{i c} w_{i c}, \sum_{i=4}^{5} x_{i c} w_{i c}\right)$, it becomes evident that significant discrepancies do exist. For example, on the regional level, subindicator $\mathrm{X}_{4}$ has a proportional share of more than $40 \%$ in 3 counties (County of Virovitica-Podravina, County of Slavonski Brod-Posavina and County of Vukovar-Sirmium) while for the case of the County of Slavonski Brod-Posavina, the proportional share of the demographic category exceeds $95 \%$. At the local level, 94 local units have a demographic category share greater than $40 \%$. The average proportional shares of sub-indicators and category shares are presented in Table 2 .

\begin{tabular}{|l|c|c|c|c|c|c|c|}
\hline Sub-indicator & $\mathrm{X}_{1}(\%)$ & $\mathrm{X}_{2}(\%)$ & $\mathrm{X}_{3}(\%)$ & $\mathrm{X}_{4}(\%)$ & $\mathrm{X}_{5}(\%)$ & $\begin{array}{c}\text { Economic } \\
(\%)\end{array}$ & $\begin{array}{c}\text { Demographic } \\
(\%)\end{array}$ \\
\hline Local level & 20.29 & 10.40 & 34.94 & 19.23 & 15.15 & 65.63 & 34.37 \\
\hline $\begin{array}{l}\text { Regional } \\
\text { level }\end{array}$ & 19.93 & 12.08 & 31.52 & 19.17 & 17.30 & 63.53 & 36.47 \\
\hline
\end{tabular}

Table 2: Average proportional shares of sub-indicators and the average category share

\subsection{Data driven weights: applied to the development index}

\subsubsection{Multivariate analysis}

Composite indicators often include some of the indicators with which they are being correlated, leading to double counting [12]. Still, it is not strictly necessary to exclude highly collinear variables. High correlation between indicators could be seen as a problem which should be corrected by making appropriate weights. Two indicators, income per capita and local budget revenue, are highly correlated. Since local revenues depend mostly on tax revenues, especially on income tax and surtax on income tax [15], the inclusion of both indicators may be redundant. Both indicators were retained in further analysis.

\begin{tabular}{|l|l|l|l|l|l|}
\hline & $X_{1}$ & $X_{2}$ & $X_{3}$ & $X_{4}$ & $X_{5}$ \\
\hline$X_{1}$ & 1 & & & & \\
\hline$X_{2}$ & 0.92 & 1 & & & \\
\hline$X_{3}$ & -0.68 & -0.67 & 1 & & \\
\hline$X_{4}$ & 0.44 & 0.55 & -0.59 & 1 & \\
\hline$X_{5}$ & 0.79 & 0.81 & -0.57 & 0.66 & 1 \\
\hline
\end{tabular}

Table 3: Correlation matrix; regional level

\begin{tabular}{|l|l|l|l|l|l|}
\hline & $X_{1}$ & $X_{2}$ & $X_{3}$ & $X_{4}$ & $X_{5}$ \\
\hline$X_{1}$ & 1 & & & & \\
\hline$X_{2}$ & 0.51 & 1 & & & \\
\hline$X_{3}$ & -0.67 & -0.48 & 1 & & \\
\hline$X_{4}$ & 0.25 & 0.51 & -0.39 & 1 & \\
\hline$X_{5}$ & 0.73 & 0.55 & -0.55 & 0.51 & 1 \\
\hline
\end{tabular}

Table 4: Correlation matrix; local level 
PCA was based on a correlation matrix of the components. The latent root criterion was applied to verify the a priori criterion for selecting only the first component $I^{P C A}$. PCA analysis on the regional level and based on the correlation matrix resulted with only one eigenvalue exceeding 1.0, indicating a single retaining component that explained $74 \%$ of the total variance. On the local level, PCA analysis also resulted in only one eigenvalue exceeding 1.0, indicating a single retaining component that explained $62 \%$ of the total variance. On the local level, the PCA was also performed after the exclusion of an outlier where the results were almost equivalent as without outlier exclusion. PCA can lead to different results using factor rotation - a problem some cite as a drawback of the method. Table 5 shows the weights obtained by PCA and scaled to a unity sum.

\begin{tabular}{|l|c|c|c|c|c|c|}
\hline Normalized weights $w^{P C A}$ & $w_{1}^{P C A}$ & $w_{2}^{P C A}$ & $w_{3}^{P C A}$ & $w_{4}^{P C A}$ & $w_{5}^{P C A}$ & Variance explained (\%) \\
\hline Local level & 0.21 & 0.2 & 0.2 & 0.17 & 0.22 & 62 \\
\hline $\begin{array}{l}\text { Local level } \\
\text { Outlier excluded }\end{array}$ & 0.21 & 0.19 & 0.2 & 0.17 & 0.21 & 63 \\
\hline Regional level & 0.21 & 0.22 & 0.19 & 0.17 & 0.21 & 74 \\
\hline
\end{tabular}

Table 5: Normalized weights derived from PCA

The results of PCA at the local level are presented graphically and compared to the original values of the development index (Figure 1).

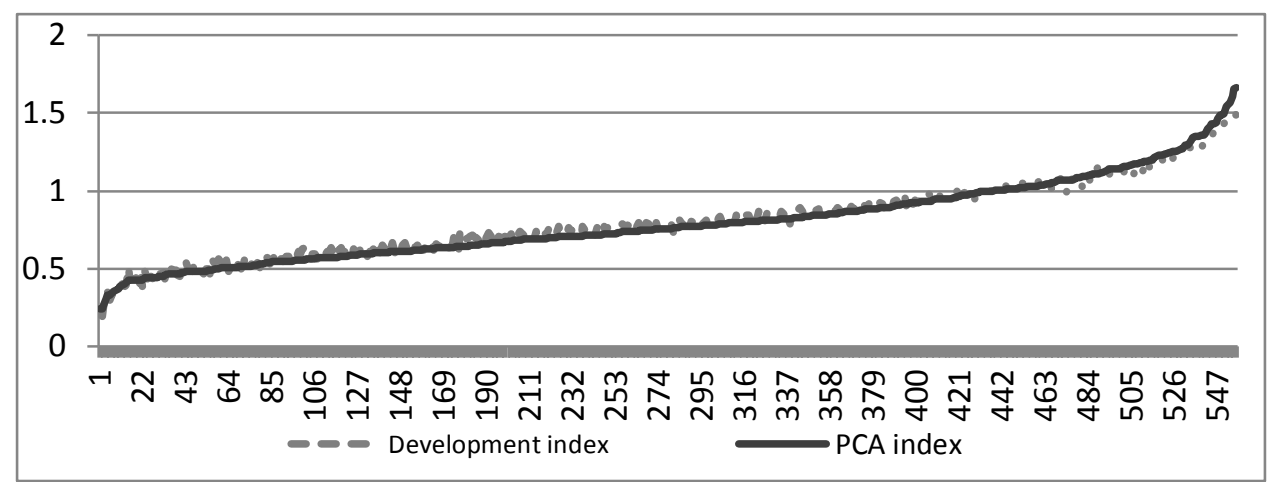

Figure 1: PCA derived indicator vs the development index, on the local level

Compared with the values of $I^{P C A}$, the $I^{G O V}$ underestimates the development level of the local units classified in Groups 1 and 5 (low and high development level), while overestimating the development level of units classified in Groups 2,3 and 4 (medium development level). Figure 2 presents the difference $I^{P C A_{-}}$ $I^{G O V}$ relative to the mean index value $\left(I^{P C A}+I^{G O V}\right) / 2$ and revealing the latter statement. 


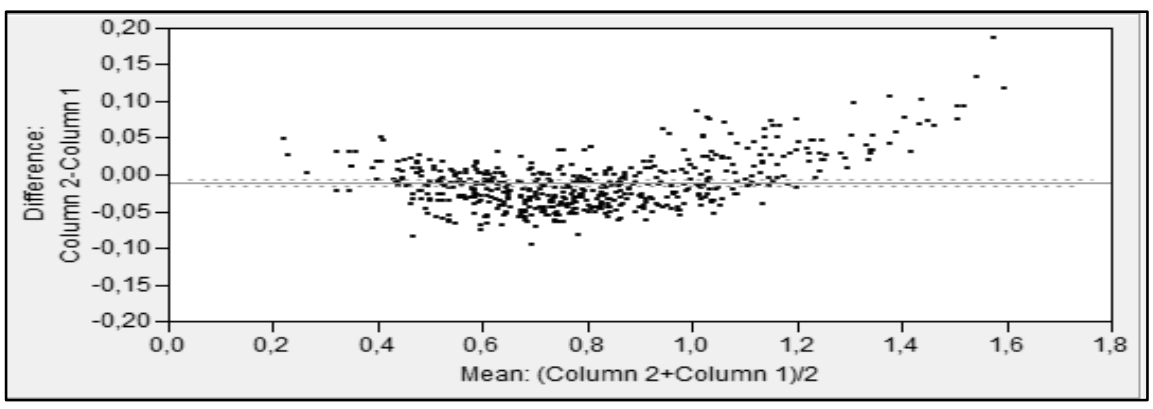

Figure 2: The difference between $P^{P C A}$ and $Y^{O O V}$, on the local level

The uncertainty analysis is conducted using Monte Carlo simulation. As mentioned in the second section, this paper assumes weight setting as the only type of uncertain input. For each sub-indicator, 500 weights from uniform distribution $\mathrm{U}(0.1,0.6)$ were generated. Afterwards, the weights were scaled to a unity sum. The latter ensured the weights ranged between 0.04 and 0.6. For each local unit, 500 values of a new CI were computed together with a relative frequency of classification into groups defined by $I^{G O V}$ (Table 1). The results of the Monte Carlo simulation reveal that 82 local units are probably misclassified since the relative frequency of classification into the group assigned by $I^{G O V}$ is lower than $50 \%$. On average, the local units did not change assigned groups in $80 \%$ of simulations.

CI values and corresponding ranks of the regional units were computed using PCA weights, and presented in Table 6 together with the linear programming and simulation results.

\subsubsection{The Benefit-of-the-Doubt approach and simple linear optimization}

Due to the complexity of operations, linear programming methods were applied only to units on a regional level. Two types of sub-indicator share restrictions were imposed: a proportional sub-indicator share restrictions (8) and restrictions pertaining to category shares (9). When applying the min-max normalization and the general normalization (7), it is possible to set only the upper bound for each proportional sub-indicator share (8). This upper bound was set to $50 \%$ higher than the weights determined by the government decree, $w_{q}^{G O V}$. In the second case (9), restrictions on two category shares, economic and demographic, were established. The upper bound was set to $25 \%$ higher than the sum of the corresponding government's weights, while the lower bound is the sum decreased by $25 \%$ (in the case of the economic indicator, the sum of weights is equal to 0.7, while in the case of demographic indicators, it is 0.3). Category share restrictions lead to a domination of a single indicator in each category, the other sub-indicators do not matter, as their relative weight is equal to zero. 
Sub-indicator share restrictions

$$
\frac{x_{i c} w_{i c}}{\sum_{i=1}^{5} x_{i c} w_{i c}} \leq 1.5 w_{q}^{G O V}, q=1, \ldots, 5
$$

Restrictions pertaining to category shares

$$
\begin{aligned}
& 0.525 \leq \frac{\sum_{i=1}^{3} x_{i c} w_{i c}}{\sum_{i=1}^{5} x_{i c} w_{i c}} \leq 0.875 \\
& 0.225 \leq \frac{\sum_{i=4}^{5} x_{i c} w_{i c}}{\sum_{i=1}^{5} x_{i c} w_{i c}} \leq 0.375
\end{aligned}
$$

Despite the introduction of new restrictions, all units still achieved the value of 1 , the maximal value of the CI. To overcome this, a common condition for every unit $c \sum_{i=1}^{5} w_{i}=1$ was introduced. Since the values of the BOD development index are bounded by 1 they are not directly comparable to the original values of the development index. Subsequently, the corresponding ranks were compared (Table 6).

The condition $\sum_{i=1}^{Q} x_{i c} w_{i c} \leq 1$ ensures an upper bound for the CI-value. While the government's methodology allows values for the development index to be greater than one, which clearly has a natural interpretation, the specified condition was excluded and two simple linear optimization problems (10a, 10b) were also conducted. The maximum values obtained from the optimization problems (10a) and (10b) are now comparable to the original values of a development index $I^{G O V}$ and to the values obtained from PCA, I $I^{P C A}$ (Table 6).

$$
\begin{aligned}
& C I^{*}=\max _{w_{i c}} \sum_{i=1}^{Q} x_{i c} w_{i c} \quad C I^{*}=\max _{w_{i c}} \sum_{i=1}^{Q} x_{i c} w_{i c} \\
& \sum_{i=1}^{Q} w_{i c}=1, c=1, \ldots, C \quad \text { (10a) } \quad \sum_{i=1}^{Q} w_{i c}=1, c=1, \ldots, C \\
& \frac{x_{i c} w_{i c}}{\sum_{i=1}^{5} x_{i c} w_{i c}} \leq 1.5 w_{q}^{G O V}, \quad q=1, \ldots, 5 \quad 0.525 \leq \frac{\sum_{i=1}^{3} x_{i c} w_{i c}}{\sum_{i=1}^{5} x_{i c} w_{i c}} \leq 0.875 \\
& w_{i c} \geq 0, q=1, \ldots, Q, c=1, \ldots, C \\
& 0.225 \leq \frac{\sum_{i=4}^{5} x_{i c} w_{i c}}{\sum_{i=1}^{5} x_{i c} w_{i c}} \leq 0.375 \\
& w_{i c} \geq 0, q=1, \ldots, Q, c=1, \ldots, C
\end{aligned}
$$

The uncertainty analysis is conducted using Monte Carlo simulation. For each indicator, 1000 weights from the distribution $\mathrm{U}(0.1,0.6)$ were generated. Afterwards, weights were scaled to a unity sum. For each regional unit, 1000 values of a new CI were computed and a $90 \%$ confidence interval was estimated. Furthermore, a relative frequency of classification into groups defined by the development index was computed for each county. Only one county, SplitDalmatia, was found to be misclassified by government weights; $71 \%$ of conducted simulations provided a classification into the group with a higher development level. 


\begin{tabular}{|c|c|c|c|c|c|c|c|}
\hline \multirow[t]{2}{*}{ County of } & \multicolumn{2}{|c|}{$\begin{array}{c}\text { Min max } \\
\text { normalization }\end{array}$} & \multicolumn{2}{|c|}{$\begin{array}{l}\text { Governmental } \\
\text { normalization }\end{array}$} & \multirow{2}{*}{$I^{P C A}$} & \multirow{2}{*}{$I^{G O V}$} & \multirow{2}{*}{$\begin{array}{l}90 \% \text { confidence } \\
\text { interval }\end{array}$} \\
\hline & $10 b^{*}$ & $10 a^{*}$ & $10 \mathrm{~b}$ & $10 \mathrm{a}$ & & & \\
\hline $\begin{array}{l}\text { Virovitica- } \\
\text { Podravina }\end{array}$ & $\begin{array}{c}0.06 \\
(2) \\
\end{array}$ & $\begin{array}{c}0.0154 \\
(1) \\
\end{array}$ & $\begin{array}{c}0.13 \\
(2)\end{array}$ & $\begin{array}{c}0.04 \\
(2)\end{array}$ & $\begin{array}{r}0.07 \\
(1)\end{array}$ & $\begin{array}{c}0.06 \\
(1)\end{array}$ & $<0.05,0.09>$ \\
\hline $\begin{array}{l}\text { Slavonski } \\
\text { Brod-Posavina }\end{array}$ & $\begin{array}{c}0.03 \\
(1)\end{array}$ & $\begin{array}{c}0.0155 \\
(2)\end{array}$ & $\begin{array}{c}0.04 \\
(1)\end{array}$ & $\begin{array}{c}0.03 \\
(1)\end{array}$ & $\begin{array}{c}0.22 \\
(4)\end{array}$ & $\begin{array}{c}0.18 \\
(2)\end{array}$ & $<0.15,0.33>$ \\
\hline $\begin{array}{l}\text { Vukovar- } \\
\text { Sirmium }\end{array}$ & $\begin{array}{c}0.07 \\
(3)\end{array}$ & $\begin{array}{c}0.06 \\
(3)\end{array}$ & $\begin{array}{c}0.14 \\
(3) \\
\end{array}$ & $\begin{array}{c}0.12 \\
(3) \\
\end{array}$ & $\begin{array}{c}0.22 \\
(2)\end{array}$ & $\begin{array}{c}0.19 \\
(3) \\
\end{array}$ & $<0.16,0.29>$ \\
\hline $\begin{array}{l}\text { Bjelovar } \\
\text { Bilogora }\end{array}$ & $\begin{array}{c}0.15 \\
(4)\end{array}$ & $\begin{array}{c}0.13 \\
(4) \\
\end{array}$ & $\begin{array}{c}0.27 \\
(4)\end{array}$ & $\begin{array}{c}0.25 \\
(4)\end{array}$ & $\begin{array}{c}0.22 \\
(3) \\
\end{array}$ & $\begin{array}{c}0.23 \\
(4) \\
\end{array}$ & $<0.21,0.23>$ \\
\hline $\begin{array}{l}\text { Požega- } \\
\text { Slavonia }\end{array}$ & $\begin{array}{c}0.31 \\
(6) \\
\end{array}$ & $\begin{array}{c}0.19 \\
(5) \\
\end{array}$ & $\begin{array}{c}0.55 \\
(5) \\
\end{array}$ & $\begin{array}{c}0.38 \\
(5) \\
\end{array}$ & $\begin{array}{c}0.29 \\
(5) \\
\end{array}$ & $\begin{array}{c}0.34 \\
(5) \\
\end{array}$ & $<0.23,0.37>$ \\
\hline $\begin{array}{l}\text { Sisak- } \\
\text { Moslavina }\end{array}$ & $\begin{array}{c}0.32 \\
(7) \\
\end{array}$ & $\begin{array}{c}0.21 \\
(6) \\
\end{array}$ & $\begin{array}{c}0.64 \\
(7) \\
\end{array}$ & $\begin{array}{c}0.42 \\
(6) \\
\end{array}$ & $\begin{array}{c}0.42 \\
(6) \\
\end{array}$ & $\begin{array}{c}0.39 \\
(6) \\
\end{array}$ & $<0.32,0.48>$ \\
\hline Osijek-Baranja & $\begin{array}{c}0.30 \\
(5) \\
\end{array}$ & $\begin{array}{c}0.24 \\
(7) \\
\end{array}$ & $\begin{array}{c}0.59 \\
(6)\end{array}$ & $\begin{array}{c}0.54 \\
(7) \\
\end{array}$ & $\begin{array}{c}0.49 \\
(7) \\
\end{array}$ & $\begin{array}{c}0.46 \\
(7)\end{array}$ & $<0.44,0.55>$ \\
\hline Karlovac & $\begin{array}{c}0.39 \\
(8) \\
\end{array}$ & $\begin{array}{c}0.34 \\
(9) \\
\end{array}$ & $\begin{array}{c}0.77 \\
(8) \\
\end{array}$ & $\begin{array}{c}0.69 \\
(9) \\
\end{array}$ & $\begin{array}{c}0.54 \\
(9) \\
\end{array}$ & $\begin{array}{c}0.56 \\
(8) \\
\end{array}$ & $<0.45,0.61>$ \\
\hline $\begin{array}{l}\text { Koprivnica- } \\
\text { Križevci }\end{array}$ & $\begin{array}{c}0.45 \\
(9) \\
\end{array}$ & $\begin{array}{c}0.32 \\
(8) \\
\end{array}$ & $\begin{array}{c}0.87 \\
(9) \\
\end{array}$ & $\begin{array}{c}0.69 \\
(8) \\
\end{array}$ & $\begin{array}{c}0.52 \\
(8) \\
\end{array}$ & $\begin{array}{c}0.59 \\
(9) \\
\end{array}$ & $<0.41,0.64>$ \\
\hline Lika-Senj & $\begin{array}{l}0.51 \\
(10) \\
\end{array}$ & $\begin{array}{l}0.39 \\
(12) \\
\end{array}$ & $\begin{array}{l}0.91 \\
(10) \\
\end{array}$ & $\begin{array}{l}0.79 \\
(12) \\
\end{array}$ & $\begin{array}{l}0.61 \\
(10) \\
\end{array}$ & $\begin{array}{l}0.65 \\
(10) \\
\end{array}$ & $<0.5,0.7>$ \\
\hline Međimurje & $\begin{array}{l}0.61 \\
(14) \\
\end{array}$ & $\begin{array}{c}0.377 \\
(10)\end{array}$ & $\begin{array}{l}1.15 \\
(14) \\
\end{array}$ & $\begin{array}{l}0.74 \\
(10) \\
\end{array}$ & $\begin{array}{l}0.62 \\
(12) \\
\end{array}$ & $\begin{array}{l}0.70 \\
(11) \\
\end{array}$ & $<0.52,0.78>$ \\
\hline $\begin{array}{l}\text { Krapina- } \\
\text { Zagorje }\end{array}$ & $\begin{array}{l}0.54 \\
(12)\end{array}$ & $\begin{array}{l}0.38 \\
(11)\end{array}$ & $\begin{array}{l}0.96 \\
(12)\end{array}$ & $\begin{array}{l}0.78 \\
(11)\end{array}$ & $\begin{array}{l}0.61 \\
(11)\end{array}$ & $\begin{array}{l}0.73 \\
(12)\end{array}$ & $<0.51,0.74>$ \\
\hline Šibenik-Knin & $\begin{array}{l}0.56 \\
(13)\end{array}$ & $\begin{array}{l}0.47 \\
(13)\end{array}$ & $\begin{array}{l}0.94 \\
(11)\end{array}$ & $\begin{array}{l}0.91 \\
(13)\end{array}$ & $\begin{array}{l}0.82 \\
(14) \\
\end{array}$ & $\begin{array}{l}0.81 \\
(13)\end{array}$ & $<0.76,0.89>$ \\
\hline Varaždin & $\begin{array}{l}0.66 \\
(15) \\
\end{array}$ & $\begin{array}{c}0.484 \\
(15) \\
\end{array}$ & $\begin{array}{l}1.17 \\
(15) \\
\end{array}$ & $\begin{array}{l}0.94 \\
(14) \\
\end{array}$ & $\begin{array}{l}0.77 \\
(13) \\
\end{array}$ & $\begin{array}{l}0.86 \\
(14) \\
\end{array}$ & $<0.68,0.89>$ \\
\hline Split-Dalmatia & $\begin{array}{l}0.53 \\
(11)\end{array}$ & $\begin{array}{c}0.476 \\
(14)\end{array}$ & $\begin{array}{l}1.05 \\
(13) \\
\end{array}$ & $\begin{array}{l}0.97 \\
(15)\end{array}$ & $\begin{array}{l}1.01 \\
(15) \\
\end{array}$ & $\begin{array}{l}0.94 \\
(15)\end{array}$ & $<0.91,1.13>$ \\
\hline Zadar & $\begin{array}{l}0.76 \\
(16) \\
\end{array}$ & $\begin{array}{l}0.63 \\
(16)\end{array}$ & $\begin{array}{l}1.34 \\
(16) \\
\end{array}$ & $\begin{array}{l}1.18 \\
(16) \\
\end{array}$ & $\begin{array}{l}1.09 \\
(16) \\
\end{array}$ & $\begin{array}{l}1.06 \\
(16) \\
\end{array}$ & $<0.96,1.3>$ \\
\hline $\begin{array}{l}\text { Dubrovnik- } \\
\text { Neretva }\end{array}$ & $\begin{array}{l}0.78 \\
(17)\end{array}$ & $\begin{array}{c}0.697 \\
(17)\end{array}$ & $\begin{array}{l}1.36 \\
(17)\end{array}$ & $\begin{array}{l}1.33 \\
(17)\end{array}$ & $\begin{array}{l}1.22 \\
(18)\end{array}$ & $\begin{array}{l}1.21 \\
(17)\end{array}$ & $<1.16,1.3>$ \\
\hline Zagreb & $\begin{array}{l}0.84 \\
(19) \\
\end{array}$ & $\begin{array}{l}0.70 \\
(18)\end{array}$ & $\begin{array}{l}1.59 \\
(18) \\
\end{array}$ & $\begin{array}{l}1.38 \\
(18) \\
\end{array}$ & $\begin{array}{l}1.18 \\
(17) \\
\end{array}$ & $\begin{array}{l}1.24 \\
(18)\end{array}$ & $<1.09,1.33>$ \\
\hline $\begin{array}{l}\text { Primorje- } \\
\text { Gorski kotar }\end{array}$ & $\begin{array}{l}0.82 \\
(18)\end{array}$ & $\begin{array}{l}0.75 \\
(19)\end{array}$ & $\begin{array}{l}1.68 \\
(19)\end{array}$ & $\begin{array}{l}1.49 \\
(19)\end{array}$ & $\begin{array}{l}1.42 \\
(19)\end{array}$ & $\begin{array}{l}1.39 \\
(19)\end{array}$ & $<1.32,1.48>$ \\
\hline Istria & $\begin{array}{l}0.93 \\
(20) \\
\end{array}$ & $\begin{array}{l}0.84 \\
(20) \\
\end{array}$ & $\begin{array}{l}1.75 \\
(20) \\
\end{array}$ & $\begin{array}{l}1.69 \\
(20) \\
\end{array}$ & $\begin{array}{l}1.54 \\
(20) \\
\end{array}$ & $\begin{array}{l}1.57 \\
(20) \\
\end{array}$ & $<1.46,1.63>$ \\
\hline City of Zagreb & $\begin{array}{l}1.00 \\
(21)\end{array}$ & $\begin{array}{l}0.97 \\
(21)\end{array}$ & $\begin{array}{l}2.18 \\
(21)\end{array}$ & $\begin{array}{l}1.99 \\
(21)\end{array}$ & $\begin{array}{l}1.88 \\
(21)\end{array}$ & $\begin{array}{l}1.86 \\
(21)\end{array}$ & $<1.7,2.01>$ \\
\hline
\end{tabular}

Table 6: CI values using different weighting schemes, regional level

\section{Conclusion}

The main instrument of Croatian regional policy is the development index. This index is a composite indicator constructed with the aim of assessing the 
development level of Croatian territorial units (towns, municipalities and counties) and is calculated as the weighted average of five basic normalized socio-economic indicators.

Composite indicators are increasingly becoming a useful tool for policy evaluation and public communication. However, if poorly constructed, composite indicators can be used to send misleading policy messages or even manipulate results. The subjectivity involved in constructing CIs, for instance, if the weighting procedures are not transparent, is the cause of doubts concerning the credibility of the CI. One of the most difficult aspects of constructing CI is choosing weights for the components.

This paper focuses on weight setting as the only source of uncertainty, while keeping other types of uncertainties such as the selection of sub-indicators and data normalization fixed. Uncertainty and sensitivity analysis may increase transparency or make policy inference more defensible. While the uncertainty analysis conducted in this paper is somewhat partial, a recommendation for future work would be a synergic use of these two methods including all sources of uncertainty. The goal of this paper was to propose an empirical approach for weight selection and to contribute to a better understanding of the complexity of CIs with the aim of improving techniques currently used to build the development index. PCA was undertaken and resulted in similar weights on the local and regional level. On the regional level, linear programming tools provided county specific weights maximizing the CI value subject to the subindicator proportional share restrictions and category restrictions. These restrictions enable inclusion of expert opinion, thus allowing for an easy and natural interpretation of previous information on the importance of CI components. Monte Carlo simulations provided confidence intervals for the development index instead the unique point estimation, and served for estimation of misclassification purposes based the values of the development index. The main advantage of the proposed methods is non-subjectivity. Simulations incorporate uncertainty in the construction of composite indicators, but they do not allow ranking of units. On the other hand, the BOD approach ensures unit-specific weights, which ensure a maximum value of a CI for every territorial unit and allow for unit ranking. Thus, pairwise comparison of units is possible.

The classification of Croatian territorial units for regional policy purposes is based on the value of the development index. Different classifications result in different beneficiaries and different incentive intensity. Thus, for many local/regional units, categorization under the development index is crucial for further development. This paper shows that the examined weighting schemes result in different categorization of territorial units, thus it is important to be aware that weights do matter. 


\section{References}

[1] Booysen, F. (2002). An overview and evaluation of composite indices of development. Social Indicators Research, 59, 115-151.

[2] Charnes, A., Cooper, W.W. and Rhodes, E. (1978). Measuring the efficiency of decision making units. European Journal of Operational Research, 2, 429-444.

[3] Cherchye, L., Moesen, W., Rogge, N. and Van Puyenbroeck, T. (2007). An introduction to 'benefit of the doubt' composite indicators. Social Indicators Research, 82(1), 111-145. doi:10.1007/s11205-006-9029-7.

[4] Cherchye, L., Moesen, W., Rogge, N., Van Puyenbroeck, T., Saisana, M., Saltelli, A., Liska, R. and Tarantola, S. (2008). Creating composite indicators with DEA and robustness analysis: The case of the technology achievement index. Journal of the Operational Research Society, 58, 239-251.

[5] Cziraky, D., Sambdt, J., Rovan, J. and Puljiz, J. (2005). Regional development assessment: A structural equation approach. European Journal of Operational Research, 74(1), 427-442. doi:10.1016/j.ejor.2005.03.012.

[6] Decree on amendments to the decree on development index. Official Gazette, No. 158/13. http://narodne-novine.nn.hr/clanci/sluzbeni/2013_12_158_3312.html [Accessed on 10 March 2014].

[7] Decree on development index. Official Gazette, No. 63/10 http://narodne-novine.nn.hr/clanci/sluzbeni/2010_05_63_1999.html] [Accessed on 15 February 2014].

[8] Despotis, D.K. (2005). A reassessment of the human development index via data envelopment analysis. The Journal of the Operational Research Society, 56(8), 969980. doi:10.1057/palgrave.jors.2601927.

[9] Hair, J.F., Anderson, R. E., Tatham R. L. and Black, W. C. (1995). Multivariate Data Analysis: With Readings. Fourth Edition. New Jersey: Prentice Hall.

[10] Law on regional development. Official Gazette, No. 153/09 http://narodne-novine.nn.hr/default.aspx [Accessed on 15 February 2014].

[11] Mahlberg, B. and Obersteiner, M. (2001). Remeasuring the HDI by data envelopment analysis. Interim Report IR-01-069, Laxenburg: International Institute for Applied System Analysis.

[12] Nardo, M., Saisana, M., Saltelli, A., Tarantola, S., Hoffman, A. and Giovannini, E. (2005). Handbook on constructing composite indicators: Methodology and user guide. OECD Statistics Working Paper STD/DOC. http://www.oecd.org/ [Accessed on 01 April 2014].

[13] Nguefack-Tsague, G., Klasen, S. and Zucchini, W. (2011). On weighting the components of the Human Development Index: A statistical justification. Journal of Human development and Capabilities, 12(2), 183-202. doi:10.1080/19452829.2011.571077.

[14] Noorbakhsh, F. (1998). The human development index: Some technical issues and alternative indices. Journal of International Development, 10(5), 589-605. doi:10.1002/(SICI)1099-1328(199807/08)10:5<589::AID-JID484>3.0.CO;2-S.

[15] Ott, K., Bajo, A., Bronić, M., Bratić, V. and Medak Fell, D. (2009). A Citizen's Guide to the Budget. Second Edition. Zagreb: Institute for Public Finance. 
[16] Paruolo, P., Saisana, M. and Saltelli, A. (2013). Ratings and rankings: Voodoo or science? Journal of the Royal Statistical Society: Series A (Statistics in Society), 176(3), 609-634. doi:10.1111/j.1467-985x.2012.01059.x.

[17] Perišić, A. (2014) Multivariate classification of local and regional government units according to socio-economic development. Društvena istraživanja (Social Studies), 23(2), 211-231. doi:10.5559/di.23.2.01.

[18] Perišić, A. and Wagner V. (2014). The development index - analysis of a basic instrument of regional policy of the Republic of Croatia, submitted for publication.

[19] Puljiz, J. (2007). Proposal for new development categorization on regional and local units in Croatia. Croatian International Relations Review, 12, 44/45.

[20] Saisana, M., Saltelli, A. and Tarantola, S. (2005). Uncertainty and sensitivity analysis techniques as tools for the quality assessment of composite indicators. Journal of the Royal Statistical Society-A, 168(2), 307-323.

[21] Schmidtlein, M. C., Deutsch, R. C., Piegorsch, W. W. and Cutter, S. L. (2008). A sensitivity analysis of the social vulnerability index. Risk Analysis, 28(4), 1099-1114. doi:10.1111/j.1539-6924.2008.01072.x.

[22] Shen, Y., Hermans, E., Brijs, T. and Wets, G. (2013). Data envelopment analysis for composite indicators: A multiple layer model. Social Indicators Research, 114(2), 739-756. doi:10.1007/s11205-012-0171-0.

[23] Singh, R.K., Murty, H.R., Gupta, S.K. and Dikshit, A.K. (2012). An overview of sustainability assessment methodologies. Ecological Indicators, 15, 281-299. doi:10.1016/j.ecolind.2008.05.011.

[24] Timm, H.N. (2002). Applied Multivariate Statistics. New York: Springer

[25] Toffalis ,C. (2013). An automatic-democratic approach to weight setting for the new human development index. Journal of Population Economics, 26(4), 1325-1345. doi:10.1007/s00148-012-0432-x. 